\title{
HUBUNGAN TINGKAT PENGETAHUAN DENGAN PRAKTIK SADARI PADA WANITA USIA SUBUR DI KELURAHAN KEMIJEN SEMARANG TIMUR KOTA SEMARANG
}

\author{
Sri Mularsih ${ }^{1}$, Frida Cahyaningrum ${ }^{2}$, Endang Sri Rubiyanti ${ }^{3}$ \\ Email : srimularsih88@gmail.com; ningnongndut@rocketmail.com \\ Akademi Kebidanan Abdi Husada Semarang \\ Jalan HR.Hadianto No.70 Banaran, Gunungpati, Kota Semarang \\ Telp. (024). 8508310
}

\begin{abstract}
Abstrak
Deteksi dini memegang peranan penting untuk mengatasi terjadinya kanker payudara dengan cara melakukan pemeriksaan payudara sendiri (SADARI). Penelitian ini bertujuan untuk mengetahui hubungan tingkat pengetahuan dengan praktik pemeriksaan payudara sendiri (SADARI) pada wanita usia subur (WUS) di RT IV/ RW 01 kelurahan Kemijen Semarang Timur Kota Semarang.

Jenis penilitian ini adalah penelitian studi korelasi dengan pendekatan penelitian rancangan cross sectional. Populasi dalam penilitian ini sebanyak 42 Wanita Usia Subur (WUS) di RT IV/ RW 01 kelurahan Kemijen Semarang Timur Kota Semarang. Sedangkan sampel yang dipakai dalam penelitian ini seluruh wanita usia subur berjumlah 42 orang dengan teknik pengambilan sampel teknik sampling jenuh.

Hasil penelitian yang dilakukan peneliti didapatkan sebagian besar berumur 20 - 35 tahun sebanyak 23 responden $(55.8 \%)$. Sebagian besar tingkat pendidikan responden adalah tamat SMP sebanyak 19 responden (45.2\%). Sebagian besar responden sebanyak 24 responden $(57,1 \%)$ dengan pengetahuan cukup. Sebagian responden sebanyak 30 responden (71,4\%) yang melakukan praktik SADARI. Ada hubungan pengetahuan dengan praktik SADARI di RT IV/ RW 01 kelurahan Kemijen, Semarang Timur, kota Semarang, didapatkan Chi square sebesar 7.586, $p$ value sebesar 0.023. Saran yang dapat diberikan kepada ibu hendaknya mencari informasi kepada tenaga kesehatan tentang cara melakukan pemeriksaan payudara sendiri (SADARI), sehingga para ibu mengetahui pentingnya melakukan sendiri pemeriksaan SADARI untuk mengetahui terjadinya kanker payudara.
\end{abstract}

Kata Kunci : : Pengetahuan, praktik dan SADARI WUS

\section{Pendahuluan}

Payudara merupakan salah satu organ penting wanita yang erat kaitanya dengan fungsi reproduksi dan kewanitaan (kecantikan). Karena itu gangguan payudara tidak sekedar memberikan gangguan kesakitan sebagaimana penyakit pada umumnya, tetapi juga akan mempunyai efek estetika dan psikologis khusus. Bila seorang terkena kanker payudaranya, mungkin harus ditindaki dengan bedah dimana kedua payudaranya diangkat. Bisa dibayangkan bagaimana perasaan dan kehidupan kewanitaan seorang perempuan yang hidup tanpa payudara. Hanya saja tidak jarang ditemukan bahwa kalau terjadi gangguan pada payudara, seorang wanita pada awalnya tidak terlalu mengacuhkanya sampai keadaaanya menjadi serius. Akibatnya, penemuan atau deteksi dini pada kanker menjadi terlambat (Bustan,2007). Bentuk payudara biasanya terasa membesar, lunak, atau ada benjolan dan kembali normal ketika menstruasi selesai. Yang terpenting adalah mengenali perubahan mana yang biasa terjadi dan mana yang tidak (Bustan, 2007).

Kanker payudara dikenal sebagai salah satu kanker yang sering menyerang kaum wanita. Selain itu kecenderungan peningkatan prevalensinya tidak dapat dihindari. Ditambah lagi kematian karena kanker payudara masih tinggi, terutama pada Negara - Negara berkembang, karena keterlambatan diagnosis, yang berarti juga pengobatan ( Bustan, 2007 ). 
Berdasarkan data Organisasi Kesehatan Dunia (WHO, 2010), setiap tahun jumlah penderita kanker payudara bertambah sekitar 7 juta. Survey terakhir di dunia menunjukkan setiap 3 menit ditemukan penderita kanker payudara dan setiap 11 menit ditemukan seorang perempuan meninggal akibat payudara. Sementara di Indonesia, rata-rata penderita kanker payudara adalah 10 dari 100 ribu perempuan, menjadikan penyakit ini berada di urutan kedua penyakit kanker yang kerap ditemukan setelah kanker mulut rahim. Penyebab pasti kanker payudara tidak diketahui. Walaupun belum ada data yang akurat untuk menghitung frekuensi kanker payudara di Indonesia, di perkirakan insiden seluruh kanker 180 jiwa per 100.000 penduduk (Bustan, 2007).

Menurut Badan Kesehatan Dunia WHO dan serikat pengendalian kanker International Union for International Cancer Control (UICC) memprediksi akan terjadi peningkatan lonjakan penderita kanker sekitar $300 \%$ di seluruh dunia pada tahun 2030. Jumlah tersebut $70 \%$ persenya berada di Negara Berkembang seperti Indonesia. Sekitar 8-9\% wanita akan mengalami kanker payudara. Ini menjadikan kanker payudara sebagai jenis kanker yang paling banyak di temui wanita. Setiap tahun lebih dari 250000 kasus baru kanker payudara terdiagnosis di Eropa dan kurang dari 175000 di Amerika Serikat (Anonim, 2011). Didapatkan juga estimasi (perkiraan) insiden kanker payudara dalam stadium lanjut sebesar 50\%nya (Depkes RI, 2008).

Data WHO (World Health Organization)menunjukkan bahwa $78 \%$ kanker payudara terjadi pada usia 50 tahun keatas. Hanya $6 \%$-nya terjadi pada mereka yang berusia kurang dari 40 tahun. Namun belakangan ini masih banyak penderita kanker payudara terutama pada wanita yang terjadi pada usia 30 tahun (Suryaningsih, 2009).

Kanker payudara dapat dideteksi dini dengan melakukan Pemeriksaan Payudara
Sendiri (SADARI). Tindakan ini sangat penting karena hampir $85 \%$ benjolan payudara ditemukan oleh penderita sendiri. Pada wanita normal, American Cancer Society menganjurkan kepada wanita yang berusia diatas 20 tahun untuk melakukan SADARI (Pemeriksaan Payudara Sendiri) setiap bulan. Usia 35-40 tahun periksa mammografi, diatas 40 tahun melakukan cheek-up pada dokter ahli, lebih dari 50 tahun cheek-up rutin dan mammografi setiap tahun (Saryono,2009).

Wanita melakukan SADARI karena adanya dorongan rasa ingin tahu yang besar untuk mencoba segala hal yang belum diketahui. Dengan adanya pengetahuan yang luas dan keinginan wanita untuk mengetahui tentang cara melakukan pemeriksaan payudara sendiri akan memberikan hasil yang lebih baik (Notoatmodjo, 2003). Kurangnya sikap yang dimiliki oleh seorang wanita tentang SADARI akan memberikan hasil yang tidak baik karena SADARI sangat penting dilakukan sedini mungkin untuk mencegah terjadinya kanker payudara (Azwar,2005).

Ada beberapa hal yang dapat meningkatkan kanker payudara, antara lain usia, riwayat kesehatan, faktor keturunan, faktor hormonal seperti menstruasi pertama yang terlalu cepat, dan menopause lambat. Selain itu upaya menunda kehamilan atau kehamilan pertama terjadi di atas 30 tahun juga dapat meningkatkan resiko. Gaya hidup yang tidak sehat, misalnya sering mengkonsumsi makanan yang mengandung kimia atau kurang olahraga juga dapat memperbesar resiko terserang kanker payudara (Rasjidi,2010).

Di Indonesia, skrining terhadap kanker payudara masih bersifat individual sehingga program deteksi dini masih belum efisien dan efektif. Sebagai akibatnya, pasien dengan kanker payudara stadium lanjut masih cukup tinggi, yaitu lebih dari $50 \%$ (Manuba, 2010).

Jawa Tengah penderita kanker payudara pada tahun 2010 sebanyak 2.349 
kasus, tetapi pada tahun 2011 mengalami lonjakan sebanyak 4.946 kasus, dan pada tahun 2012 menurun menjadi 998 kasus (Dinas Kesehatan Kota Semarang, 2012).

Tujuan dari pemeriksaan payudara sendiri (SADARI) secara rutin adalah untuk merasakan dan mengenal lekuk-lekuk payudara sehingga jika terjadi perubahan dapat segera diketahui. Waktu terbaik untuk memeriksa payudara adalah 7 sampai 10 hari setelah menstruasi selesai. Pada saat itu, payudara terasa lunak. Pemeriksaan tidak tepat dilakukan pada menjelang dan sewaktu menstruasi. SADARI hendaknya dilakukan sendiri dengan penuh displin tiap bulan. Jika ada yang terasa lain, bergegaslah ke klinik untuk pemeriksaan payudara secara klinis atau dengan kesehatan SARANIS (Bustan, 2007).

Berdasarkan Data kejadian kanker payudara pada tahun 2012 kasus kanker payudara sebesar $0,022 \%$, kemudian mengalami kenaikan pada tahun 2013 sebesar $0,029 \%$, lalu menurun pada tahun 2014 sebesar 0,013\% (Dinas Kesehatan Kota Semarang, 2014).

Berdasarkan data dari Dinas Kesehatan Kota Semarang terdapat 37 puskesmas. Angka kejadian kanker payudara terbanyak ada di puskesmas Karangdoro sejumlah 12 kasus kanker payudara. Wilayah Kerja Puskesmas Karangdoro ada 3 wilayah yaitu Rejomulyo, Mlati Baru, dan Kemijen. Berdasarkan data dari puskesmas Karangdoro angka kejadian kanker payudara terbanyak ada di kelurahan Kemijen dimana terdapat 99 RT dalam 11 RW dan kasus kanker payudara terbanyak ada di RW 01 sejumlah 4 kasus.

Berdasarkan data dari kelurahan Kemijen pada tahun 2014 tercatat kejadian kasus kanker payudara terbanyak ada di RW 01 sejumlah 4 kasus yang terdiri dari 1 orang penderita kanker payudara yang meninggal pada bulan November 2014 dan 3 orang penderita kanker payudara yang masih hidup. Berdasarkan study pendahuluan pada bulan Februari 2015 terhadap wanita usia subur (WUS)/ responden diperoleh hasil, dari 10 WUS/ responden $3(30 \%)$ orang responden pengetahuanya baik tentang SADARI, 7 $(70 \%)$ orang responden pengetahuanya kurang tentang pengertian SADARI dan 3 responden dalam melakukan Praktik SADARI baik, 7 responden dalam melakukan Praktik SADARI kurang.Dari uraian diatas maka peneliti ingin mengetahui lebih lanjut mengenai "Hubungan Tingkat Pengetahuan dengan Praktik Pemeriksaan Payudara Sendiri (SADARI) Pada Wanita Usia Subur di RT IV/ RW 01 Kelurahan Kemijen Semarang Timur Kota Semarang”?.

\section{Metode Penelitian}

Penelitian ini menggunakan rancangan Cross Sectional yaitu suatu metode pengambilan data yang dilakukan pada waktu yang sama dengan subyek yang berbeda, metode ini bertujuan agar diperoleh data yang lengkap dalam waktu yang relatif cepat (Arikunto, 2006 ).

Jenis penelitian yang digunakan adalah penelitian korelatif yaitu pengukuran variabel terikat dan variabel bebas dalam waktu yang bersamaan untuk mencari hubungan antara dua variabel. Penelitian ini terdapat satu variabel bebas yaitu tingkat pengetahuan WUS tentang SADARI dan satu variabel terikat yaitu praktik SADARI. (Notoadmodjo, 2012).Populasi adalah keseluruhan objek penelitian atau objek yang diteliti (Notoatmodjo, 2012). Menurut pendapat Hidayat ( 2010), populasi adalah wilayah generalisasi yang terdiri atas objek atau subjek yang mempunyai kuantitas dan karakteristik tertentu yang ditetapkan oleh peneliti untuk dipelajari dan kemudian ditarik kesimpulannya. Populasi pada penelitian ini adalah wanita usia subur yang berada di RT IV/ RW01 di Wilayah Kerja Puskesmas Karangdoro Kelurahan Kemijen Kec.Semarang Timur Kota Semarang.jumlah populasi dalam penelitian ini adalah 42 wanita usia subur.

Sampel adalah sebagian yang diambil dari keseluruhan objek yang diteliti dandianggap mewakili seluruh populasi (Notoatmodjo, 2010). Dalam penelitian ini menggunakan teknik total sampling pada keseluruhan populasi, sehingga didapatkan sampel sebanyak 42 sampel. Teknik sampling merupakan teknik pengambilan sampel 
yang akan digunakan dalam penelitian. Teknik sampling dalam penelitian ini adalah sampling jenuh yaitu cara pengambilan sampel dengan mengambil semua anggota populasi menjadi sampel. Cara ini dilakukan bila populasinya kecil. Istilah lain sampling jenuh adalah sensus, dengan semua anggota populasi dijadikan sampel (Hidayat, 2010).Data pengetahuandiukur menggunakan kuisioner pada wanita usia subur dengan berbagai item pertanyaan tentang pengertian dan cara pemeriksaan sendiri, praktik diukur menggunakan kuisioner pada wanita usia subur dengan berbagai item.

Data skor pengetahuan, praktik akan dideskripsikan besarnya mean dan standar deviasi. Sedangkan kategori pengetahuan, praktik akan dideskriptifkan besarnya proporsi masing-masing kategori variable. Perhitungan rumus penentuan besarnya persentase (Notoatmodjo, 2010). Dalam menganalisis hubungan antara variable bebas (pengetahuan laktasi) dan variable terikat (praktik perawatan payudara) digunakan uji chi square $\left(X^{2}\right)$.

\section{Hasil dan Pembahasan}

A. Analisa Univariat

1) Karakteristik Wanita Usia Subur

Distribusi Frekuensi responden berdasarkan umur yang dikategorikan menjadi $\leq 19$ tahun, 20-35 tahun, dan $>35$ tahun dirangkum dalam tabel 4.1 berikut ini.

Tabel 1. Distribusi Frekuensi Responden berdasarkan Umur Wanita Usia Subur

\begin{tabular}{lll}
\hline Umur & Jumlah & Persentasi \\
\hline$\leq 19$ Tahun & 5 & 11,9 \\
\hline 20-35 Tahun & 23 & 54,8 \\
\hline$>$ 35 Tahun & 14 & 33,3 \\
\hline Total & 42 & 100,0 \\
\hline
\end{tabular}

Dari tabel 1. diatas dapat diperoleh hasil bahwa sebagian besar responden berumur 20 - 35 tahun sebanyak 23 (54.8\%) responden.

2) Pendidikan

Distribusi frekuensi responden berdasarkan tingkat pendidikan yang dikategorikan menjadi Pendidikan Dasar: tidak tamat SD, tamat SD, tamat SMP. Pendidikan Menengah: tamat SMA. Perguruan Tinggi: Akademi/ PT dapat dirangkum dalam tabel berikut ini.
Tabel 2. Distribusi Frekuensi Responden berdasarkan Tingkat Pendidikan Wanita Usia Subur

\begin{tabular}{lll}
\hline Pendidikan & Jumlah & Persentasi \\
\hline Pendidikan Dasar & 34 & 80,9 \\
\hline Menengah & 7 & 16,7 \\
\hline Perguruan Tinggi & 1 & 2,4 \\
\hline Total & 42 & 100,0 \\
\hline
\end{tabular}

Dari tabel 2. di atas dapat diperoleh hasil bahwa sebagian besar tingkat pendidikan responden adalah berpendidikan dasar sebanyak 34 (80.9\%) responden.

3) Tingkat Pengetahuan

Distribusi frekuensi responden berdasarkan tingkat pengetahuan yang dikategorikan menjadi kurang, cukup, baik dapat dirangkum dalam tabel berikut ini.

Tabel 3.Distribusi Frekuensi Responden berdasarkan Tingkat Pengetahuan Wanita Usia Subur

\begin{tabular}{lll}
\hline $\begin{array}{c}\text { Tingkat } \\
\text { Pengetahuan }\end{array}$ & Jumlah & Persentasi \\
\hline Kurang & 7 & 16,7 \\
\hline Cukup & 24 & 57,1 \\
\hline Baik & 11 & 26,2 \\
\hline Total & 42 & 100,0 \\
\hline
\end{tabular}

Dari tabel 3 di atas dapat diperoleh hasil bahwa responden dengan tingkat pengetahuan yang termasuk kategori cukup sejumlah $24(57.1 \%)$ responden.

Pengetahuan adalah merupakan hasil " tahu" dan ini terjadi setelah orang melakukan penginderaan terhadap suatu objek tertentu. Pengindraan terjadi melalui panca indra manusia, yakni indra penglihatan, pendengaran, penciuman, rasa, dan raba. Sebagian besar pengetahuan manusia diperoleh melalui mata dan telinga (Notoatmodjo, 2012).

Berdasarkan hasil penelitian di RT IV/ RW 01 Kelurahan Kemijen Semarang Timur Kota Semarang diperoleh hasil sebagian besar responden berpengetahuan cukup sebanyak 24 (57.1\%) dengan tingkat pendidikan SMP. Hal ini memberikan gambaran bahwa sebagian besar responden sudah memiliki pengetahuan yang cukup 
tentang kejadian kanker payudara. Pengetahuan responden yang cukup tersebut dapat disebabkan salah satunya dengan tingkat pendidikan, dan lingkungan, sehingga mereka telah mengetahui keadaan cara melakukan deteksi dini terjadinya kanker payudara dengan melakukan praktik SADARI. Pengetahuan seseorang biasanya diperoleh dari berbagai macam sumber. Hal ini seperti yang diungkapkan oleh Wawan dan Dewi (2010) bahwa faktor-faktor yang mempengaruhi pengetahuan antara lain faktor internal yaitu pendidikan, pekerjaan, umur, dan faktor eksternal antara lain faktor lingkungan dan social budaya.

4) Praktik SADARI

Distribusi frekuensi responden berdasarkan praktik SADARI yang dikategorikan menjadi tidak melakukan dan melakukan dapat dirangkum dalam tabel berikut ini.

Tabel 4. Distribusi Frekuensi Responden berdasarkan Praktik SADARI Wanita Usia Subur (WUS).

\begin{tabular}{ccc}
\hline Praktik & Jumlah & Persentasi \\
SADARI & &
\end{tabular}

\begin{tabular}{lll}
\hline Melakukan & 30 & 71,4 \\
\hline Tidak & 12 & 28,6 \\
Melakukan & & \\
\hline Total & 42 & 100,0 \\
\hline
\end{tabular}

Dari tabel 4 di atas dapat diperoleh hasil bahwa responden yang tidak melakukan praktik SADARI sebanyak $12(28.6 \%)$ terutama pemeriksaan SADARI di dalam aspek saya melakukan pemeriksaan payudara sendiri mulai usia 20 tahun dan saya melakukan praktik pemeriksaan payudara sendiri dengan menggunakan 3 ujung jari.

Menurut kamus besar Bahasa Indonesia, praktik adalah cara melaksanakan secara nyata apa yang disebut dalam teori. Menurut Notoatmodjo (2010). Praktik SADARI adalah pemeriksaan yang mudah dilakukan oleh setiap wanita untuk mencari benjolan atau kelainan lainnya. Berdasarkan hasil penelitian diperoleh sebagian besar responden yang melakukan praktik SADARI sebanyak $30(71.4 \%)$ responden, sedangkan yang tidak melakukan pemeriksaan SADARI sebanyak $12(28.6 \%)$ responden. Hal ini memberikan gambaran bahwa sebagian besar responden telah melakukan praktik SADARI. Karena sebagian besar responden telah mengetahui tujuan pemeriksaan SADARI yaitu menemukan penyakit dan kelainan pada payudara sehingga dapat dilakukan pengobatan sendiri serta responden mengetahui manfaat dari pemeriksaan SADARI yaitu untuk mengetahui keadaan payudara yang terlihat dan terasa normal. Sedangkan pemeriksaan SADARI dapat dilakukan satu minggu setelah haid. Jika siklus haid telah berhenti, maka sebaiknya dilakukan periksa payudara sendiri pada waktu yang sama setiap bulanya dan waktu yang dibutuhkan untuk melakukanya tidak lebih dari 5 menit.

B. Analisa Bivariat

5) Hubungan Tingkat Pengetahuan dengan Praktik SADARI

Berdasarkan Hasil uji hubungan antara tingkat pengetahuan dan praktik SADARI di RT IV/ RW 01 Kelurahan Kemijen Semarang Timur kota Semarang diperoleh hasil nilai $\mathrm{R}$ hitung $=7.586, p$ value $=0.023$

Tingkat pengetahuan dengan praktik SADARI dengan kategori kurang sejumlah 7 responden dengan perincian tingkat pengetahuan kurang melakukan pemeriksaan sebanyak 2 responden (28.6\%) dan yang tidak melakukan pemeriksaan sebanyak 5 responden (71.4\%); untuk tingkat pengetahuan dengan praktik cukup sejumlah 24 responden dengan perincian tingkat pengetahuan cukup melakukan pemeriksaan sebanyak 19 responden (79.2\%) dan yang tidak melakukan pemeriksaan sebanyak 5 responden (20.8\%); sedangkan tingkat pengetahuan baik dan pemeriksaan SADARI 
sebanyak 11 responden dengan perincian tingkat pengetahuan baik melakukan pemeriksaan sebanyak 9 responden $(81.8 \%)$ dan yang tidak melakukan pemeriksaan sebanyak 2 responden (18.2\%). Pola tersebut terbukti dengan uji chi square.

Hasil analisis statistik dengan mengggunakan uji chi square yang dilakukan terhadap tingkat pengetahuan dengan praktik SADARI di RT IV/ RW 01 Kelurahan Kemijen Semarang Timur Kota Semarang diperoleh $p$ value sebesar 0.023. Hal ini berarti bahwa ada hubungan yang signifikan antara tingkat pengetahuan dengan praktik SADARI di kelurahan Kemijen Semarang Timur kota Semarang.

Berdasarkan hasil analisis diperoleh hasil bahwa ada hubungan antara tingkat pengetahuan dengan praktik SADARI di RT IV/ RW 01 kelurahan Kemijen Semarang Timur kota Semarang sebanyak 42 responden. Hasil penelitian ini sesuai dengan teori Notoatmodjo (2003) yang menyatakan bahwa pengetahuan merupakan faktor penting dalam menentukan perilaku seseorang karena pengetahuan dapat menimbulkan perubahan persepsi dan kebiasaan masyarakat. Hal ini memberikan gambaran bahwa dengan pengetahuan yang baik seseorang akan melakukan hal-hal yang baik, karena mereka tentunya telah mengetahui manfaat yang diperoleh dengan melakukan pemeriksaan SADARI.

Dalam penelitian ini setelah ibu mengetahui apa yang dimaksud dengan pemeriksaan payudara sendiri (SADARI), kelebihan, manfaat, dan keuntungan melakukan pemeriksaan payudara sendiri (SADARI) maka timbullah pemikiran yang positif dan negative yang akhirnya akan mempengaruhi individu dalam membentuk perilaku. Hal ini sesuai dengan pendapat Notoatmodjo (2012), bahwa sikap WUS dipengaruhi oleh beberapa faktor antara lain pengalaman pribadi, pengaruh lingkungan, social budaya.

Hal ini dibuktikan adanya kecenderungan pola hubungan bahwa jika seorang wanita usia subur yang berpengetahuan kurang, mayoritas cenderung tidak melakukan praktik SADARI sedangkan seorang wanita usia subur yang berpengetahuan baik cenderung melakukan pemeriksaan SADARI. Pola tersebut terbukti dengan uji chi square. Hasil analisis statistik uji chi square diperoleh $p$ value sebesar 0.023. Hal ini berarti bahwa ada hubungan yang signifikan antara tingkat pengetahuan dengan praktik SADARI di RT IV/ RW 01 kelurahan Kemijen Semarang Timur kota Semarang.

\section{Kesimpulan}

Berdasarkan hasil penelitian yang telah peneliti lakukan di Kelurahan Kemijen mengenai pengetahuan dengan praktik pemeriksaan payudara sendiri pada wanita usia subur diperoleh kesimpulan:Responden berumur kurang dari 19 tahun sebanyak 5 $(11,9 \%)$ responden, sedangkan $23(54,8 \%)$ berumur 20-35 tahun dan $14 \quad(33,3 \%)$ berumur lebih dari 35 tahun, Sebanyak 34 $(80,9 \%)$ responden tamat $\mathrm{SD}, 7(16,7 \%)$ responden tamat SMP, dan 1 (2,4\%) responden tamat PT., Sebanyak 7 (16,7\%) responden dengan pengetahuan kurang, 24 $(57,1)$ responden dengan pengetahuan cukup dan $11(26,2 \%)$ responden dengan pengetahuan baik, Sebanyak $30(71,4 \%)$ responden melakukan praktik pemeriksaan SADARI dan $12(28,6 \%)$ responden yang tidak melakukan praktik pemeriksaan SADARI., Ada hubungan antara tingkat pengetahuan dengan praktik SADARI pada WUS di RT IV/ RW 01 Kelurahan Kemijen Semarang Timur Kota Semarang, dibuktikan dengan $p$-value 0.023

\section{DAFTAR PUSTAKA}


[1] Arikunto, S. 2006. Prosedur Penelitian. Rineka Cipta : Jakarta.

[2] Azwar, S. 2005. Sikap Manusia Teori dan Pengukuranya. Yogyakarta : Pustaka Pelajar.

[3] BKKBN.2003. Penanggulangan Masalah Kesehatan Reproduksi. Jakarta

[4] Bustan, 2007. Epidemiologi Penyakit Tidak Menular. Rineka Cipta. Jakarta.

[5] Depkes RI, 2008. Pencegahan Kanker Leher Rahim dan Kanker Payudara. Jakarta : Depkes RI.

[6] Endang, Rahayu S. 2010. Kebijakan Pengendalian Kanker Payudara. www.teknikpengendaliankankerpayuda ra.com/KMK.no796.tentangkankerpayu dara.diperoleh pada tanggal25 Maret 2014.

[7] Hidayat, AA. 2010. Metode Penelitian Kebidanan Teknik Analisis Data. Salemba Pustaka : Jakarta.

[8] Lusa.2007.http://www.lusa.web.id/peme riksaan-payudara-sendiri-sadari/. diakses pada tanggal 27 maret 2014.

[9] Luwia, M.2004. Problematik dan Perawatan Payudara. Jakarta : Kawan Pustaka.

[10] Nisman, Wenny Artanty. 2011. Kenali Payudara Anda. Andi, Yogyakarta.

[11]Notoatmodjo, S. 2012. Metodologi Penelitian Kesehatan. Jakarta : Rineka Cipta.

a. 2010.

Ilmu Perilaku Kesehatan. Jakarta : Rineka Cipta.

[12]_. 2012. Promosi Kesehatan dan Perilaku Kesehatan. Rineka Cipta, Jakarta.

[13] Ilmu, Perilaku Kesehatan. Jakarta : Rineka Cipta

[14]_ 2003. Pendidikan dan Perilaku Kesehatan. Jakarta : Rineka Cipta.

[15] Pemerintah Propinsi Jawa Tengah. Dinas Kesehatan. 2012. Profil Kesehatan Propinsi Jateng Tahun 2012. Dinkes : Semarang

[16]Rasjidi, I. 2010. 100 Questions dan Answer Kanker Payudara pada Wanita. Jakarta : Gramedia.
[17] Saryono. 2009. Perawatan Payudara. Jogjakarta : Mitra Cendikia.

[18] Wawan dan Dewi. 2010. Teori \& pengukuran Pengetahuan, Sikap dan Perilaku Manusia. Nuha Medika, Yogyakarta.

[19] Yustiana, 2013. Kanker Payudara dan Sadari. Nuha Medika, Yogyakarta. 